\title{
Higher Levels of ABA and IAA Are Found in Green than in White Asparagus Spears
}

\author{
D.J. Makus ${ }^{1}$ \\ U.S. Department of Agriculture, Agricultural Research Service, \\ Booneville, AR 72927
}

Gene Guinn ${ }^{2}$

U.S. Department of Agriculture, Agricultural Research Service, Phoenix, AZ 85040

Additional index words. abscisic acid, indole-3-acetic acid, Asparagus officinalis

Auxin (indole3-acetic acid or IAA) promotes cell elongation (Goldsmith, 1977), while abscisic acid (ABA) normally inhibits shoot growth (Bornman, 1983; Zeevaart and Creelman, 1988). We conducted a field experiment to determine if ABA and IAA concentrations differ in asparagus (Asparagus officinalis L.) spears grown in light or darkness.

Five-year-old 'Jersey Giant' asparagus plants were grown uncovered to produce green spears. White spears were produced by growing plants under opaque black rowcovers $\left(<0.2 \mu \mathrm{mol} \cdot \mathrm{m}^{-2} \cdot \mathrm{s}^{-1}\right.$ of photosynthetically active radiation at midday) as described by Makus and Gonzalez (1991), or by cutting spears that grew under $20 \mathrm{~cm}$ of sawdust mulch placed on top of the soil. The design was a randomized complete block with the three treatments replicated four times. Replicate row lengths were $7.3 \mathrm{~m}$.

All treatments were cut at the same 2- to 3-day frequency at least 10 days before the sampling data. Two to 3 days elapsed from the time of spear emergence to harvest height in all treatments. Fifteen spears from each treatment and replicate were harvested $19 \mathrm{Apr}$. 1991, washed, trimmed to $5 \mathrm{~cm}$ from the tip, frozen in liquid nitrogen, lyophilized for 72 $\mathrm{h}$, and ground in a Wiley mill through a $40-$ mesh $\left(0.36 \mathrm{~mm}^{2}\right)$ screen while purging with $\mathrm{N}$. The samples were shipped in vials under dry ice to the Western Cotton Research Laboratory, Phoenix, for analysis of ABA and MA.

Chlorophyll was removed with hexane from the green spears by acidification of the aqueous extract to $\mathrm{pH} 4$ to 4.5 with $0.5 \mathrm{~N}$ phosphoric acid. ABA and IAA levels were then determined by high-performance liquid chromatography by the method of Guinn and

Received for publication 21 Oct. 1991. Accepted for publication 3 Apr. 1992. Mention of a proprietary product does not constitute endorsement or recommendation for its use by the U.S. Dept. of Agriculture. The cost of publishing this paper was defrayed in part by the payment of page charges. Under postal regulations, this paper therefore must be hereby marked advertisement solely to indicate this fact.

'Research Horticulturist.

*Research Plant Physiologist.
Brummett (1989). Final separation was achieved on a $C_{18}$ column, having $5-\mu \mathrm{m}$ spherical particles of Adsorbosphere HS (Altech Assoc., Deerfield, Ill.), developed with $60 \%$ methanol/0.02 $\mathrm{N}$ acetic acid. Elution of IAA was monitored by native fluorescence, and ABA was monitored by absorbance at $254 \mathrm{~nm}$. The amount of each was estimated by peak height after correcting for losses during extraction and purification. Recovery of IAA ranged between $20 \%$ and $39 \%$, while recovery of ABA averaged $76 \%$.

Fresh weights of 5-cm spear tips were 2.9, 3.5 , and $3.8 \mathrm{~g}$ for control, row-covered, and sawdust-covered spears, respectively ( $P=$ $0.005)$. Corresponding dry weights were 0.28 , 0.35 , and $0.39 \mathrm{~g}$ each. Each respective treatment spear dry weight was progressively heavier $(P=0.05)$.

Green (control) spears contained higher concentrations of ABA and IAA than white spears (Fig. 1). The higher IAA concentration in green spears was consistent with their greater elongation, but the higher ABA concentration was not. The balance of growthpromoting and growth-inhibiting hormones on spear development may be more important than the concentration of any one alone. The ABA : IAA ratios were $1.57,1.74$, and 1.90 for control, row-covered, and sawdustcovered spears, respectively. Although the ratios did not differ statistically, they are consistent with the differences in spear elongation. Cytokinins and gibberellins, although not measured, may have also influenced growth.

Precursors of IAA and ABA have been found in higher concentrations in green than in white asparagus. Lai et al. (1973) reported higher levels of amino-N in green than in white asparagus. Thus, green spears may contain more tryptophan, a presumed IAA precursor. Likewise, green spears contained 1.5 times as much carotenoids as white spears (Makus and Gonzalez, 1991), consistent with the higher concentration of ABA in green spears. Carotenoids, such as 9'-cis-neoxanthin, can be used in ABA synthesis (Parry and Horgan, 1991).

In this study, the lower IAA levels in white asparagus spears may explain the shorter spear length (data not shown) observed in fieldgrown white asparagus when compared to green spears cut with the same frequency (Makus and Gonzalez, 1991). However, determining the in situ preharvest ethylene levels in green and white spears would further clarify our understanding of the role of hormones on asparagus spear development and morphology.

\section{Literature Cited}

Bornman, C.H. 1983. Morphological, anatomical, and ultrastructural responses to abscisic acid, p. 523-551. In: F.T. Addicott (ed.). Abscisic acid. Praeger Publishers, New York.

Goldsmith, M.H.M. 1977. The polar transport of auxin. Annu. Rev. Plant Physiol. 28:439-478.

Guinn, G. and D.L. Brummett. 1989. Fruiting of cotton IV. Nitrogen, abscisic acid, indole-3-acetic acid and cutout. Field Crops Res. 22:257-266.

Lai, J.H., S.C. Shen, K.M. Chiou, Y.H. Lee, and W.H. Chang. 1973. Studies on the detinning of canned asparagus. I. Effects of different materials of white and green asparagus on detinning of the canned products. J. Chinese Agr. Chem. Soc. 11:47-54.

Makus, D.J. and A.R. Gonzalez. 1991. Production and quality of white asparagus grown under opaque row covers. HortScience 26:374-377.

Parry, A.D. and R. Horgan. 1991. Carotenoids and abscisic acid (ABA) biosynthesis in higher plants. Physiol. Plant. 83:320-326.

Zeevaart, J.A.D. and R.A. Creelman. 1988. Metabolism and physiology of abscisic acid. Annu. Rev. Plant Physiol. \& Plant Molec. Biol. 39:439473.

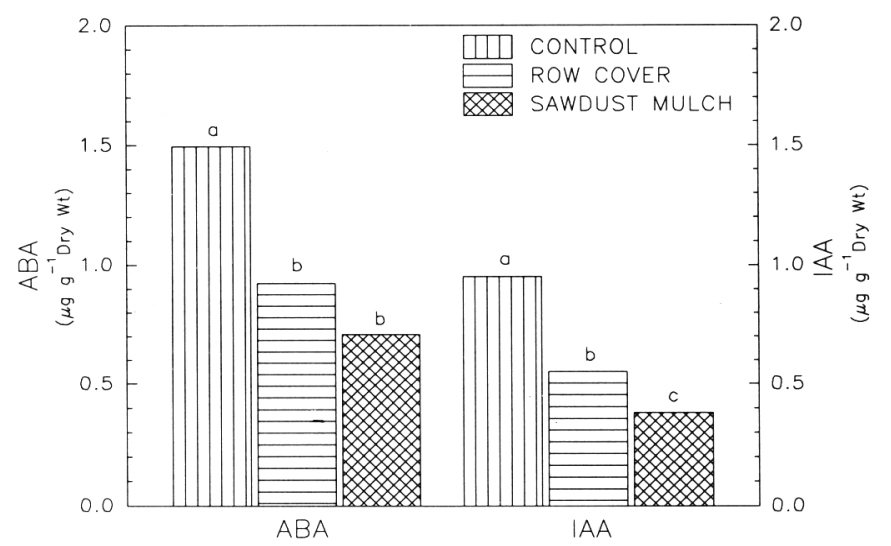

Fig. 1. $A B A$ and IAA levels in green (control) and white asparagus spears. Mean separation within hormone type, $P=0.05$. 